Scientific Journal Warsaw University of Life Sciences - SGGW

Problems of World Agriculture volume 17 (XXXII), number 4, 2017: 143-150

DOI: 10.22630/PRS.2017.17.4.90

\author{
Marzena Kacprzak ${ }^{1}$ \\ Warsaw University of Life Sciences - SGGW \\ Agnieszka Król ${ }^{2}$ \\ Warsaw Management University \\ Izabela Wielewska ${ }^{3}$ \\ UTP University of Science and Technology
}

\title{
Human Capital on the European Labour Market
}

\begin{abstract}
Efficient use of human capital and taking care of its quality in the global labour market is becoming a priority. This is primarily due to the need to function in a multicultural environment, growing competition and population aging.

This article is an attempt to systematise knowledge about human capital and its use in the labour market. Attention is being drawn to the effective use of capital, including implementation of European strategies, as well as trends and challenges facing key employment issues. In addition, an effort has been made to identify key employee competencies reflecting global labour market trends. The article shows the importance of quality and investment in human resources, which is associated with the use of EU projects and programmes targeted at young people on the labour market.
\end{abstract}

Key words: human capital, European Union, labour market, competence

JEL Classification: J24, J62, M12, M14, M54, O15, O34

\section{Introduction}

Human capital is the basic source of creating value in a global, knowledge-based economy. The uniqueness and specificity of human capital comes down to the fact that it is the only capital that cannot be copied, which is attributable to its individualism and uniqueness (Król, 2016, p. 61).

The emergence of the European Union was connected with the opening of labour markets, free movement of people, information, knowledge, goods and services, and thus improved access to employment but, at the same time, the need to increase flexibility and mobility of employees. On the one hand, membership in the EU became a great opportunity in terms of development of human capital and, on the other hand, it also brought many new challenges and problems to the global labour market.

The aim of this article is to discuss the issues of human capital in the European labour market in the context of its mobility, quality and development, and to present key trends and challenges emerging in this area.

${ }^{1} \mathrm{PhD}$, Department of European Policy and Marketing WULS-SGGW, ul. Nowoursynowska 166, 02-787 Warszawa, e-mail: marzena kacprzak@sggw.pl, https://orcid.org/0000-0002-0680-8241

${ }^{2} \mathrm{PhD}$, Warsaw Management University, ul. Kawęczyńska 36, 03-772, e-mail: krolagnieszka@op.pl, https://orcid.org/0000-0002-5685-7578

${ }^{3} \mathrm{PhD}$, UTP University of Science and Technology, Faculty of Agriculture and Biotechnology, Department of Economics and Advising in Agribusiness, ul. Ks. A. Kordeckiego 20, 85-225 Bydgoszcz, Poland, e-mail: izabel2000@wp.pl, https://orcid.org/0000-0002-1721-6890 


\section{Efficient use of human capital - European strategies}

In order to improve spatial, occupational and qualification mobility of employees, EU member states take joint action, including, among others, within the framework of the European Employment Strategy. Preparing employees for a "better" entry into the labour market is related both to increased competitiveness of EU companies and joint efforts in the fight against unemployment. After all, there is a common goal to be achieved, i.e. to make the use of human capital in the European labour market more effective. The basis for the creation of the European Employment Strategy was the formulation of the so-called White Paper guidelines in 1994 - "Growth, Competitiveness, Employment" - on how to help people seeking employment. As a result of discussion related to these issues, a new document was created, "Employment", this time as part of the Treaty of Amsterdam, thus providing the legal basis for a more engaged role of the EU in shaping the employment policy. Finally, in 1997, at the Luxembourg Summit, Government Heads of EU member states launched the European Employment Strategy (EES), also known as the "Luxembourg Process", by adopting the main employment guidelines and focusing primarily on preventive actions. The EES was based on four key pillars: employability of jobseekers, entrepreneurship, adaptability of companies and employees in a changing environment, and equal opportunities in the labour market (women - men, people with disabilities, migrants, etc.) (Szymańska, 2004, p. 4).

As part of a strategy to improve job seekers' employment opportunities, the focus was primarily on assistance targeted at young and unemployed adults, with such support being offered to young people - up to 6 months (training, retraining, internships and employment), and adults - up to 12 months (further vocational improvement and guidance). In pursuit of these goals, focus should be given to strengthening cooperation between the government, employers and employee organisations, and working out agreements that would enable the target group to participate in practical and vocational training, internships, etc. As a result, assistance could be offered to at least every fifth unemployed individual, and the number of school dropouts could be reduced. Another pillar of this strategy is related to the development of entrepreneurship - i.e. supporting people who set up their own businesses and create new jobs. The purpose is to concentrate on activities aimed to improve the process of setting up and running economic activity, by simplifying the relevant procedures, reducing taxes and costs which are not salary-related, and making use of volunteering and social cooperation. As for the third pillar - adaptability, the strategy focuses here on flexible working arrangements in cooperation with social partners and encouraging participation in training. The last pillar of the strategy is the equalisation of opportunities in the labour market by improving, among others, activation of women or people with disabilities. This could be achieved by offering, for example, support in taking care of children or the elderly, or flexible working hours (Szymańska, 2004, p. 5-6).

In 2000, the European Council developed the Lisbon Strategy - a long-term programme for the socio-economic development of Member States. The objective of this strategy was to create a dynamically developing knowledge-based world economy, aiming at full employment and building an information society.

The employment policy of the individual Member States is coordinated by the European Council and involves defining priority objectives for the implementation of employment policy in the EU Member States, on an annual basis, as well as implementing the National Action Plans, monitoring the situation on the basis of the Joint Employment 
Report (performance indicators, formulating new guidelines and recommendations to be implemented taking into account the specificity of the country concerned) (Funck, Pizzati, 2002, p. 315).

In mid-2009, work on the Europe 2020 strategy was launched. It is an EU programme aimed at growth and socio-economic development in connection with the global economic crisis, globalisation, the aging of society and the need for reasonable management of resources. This strategy should contribute to the creation of a world-wide low-carbon economy using environmentally-friendly technologies while ensuring careful use of natural resources in order to create new green jobs and enhance social cohesion. Unlike the Lisbon Strategy, Europe 2020 emphasises additionally the need for sustainable development. Three key priorities were adopted within the framework of Europe 2020: smart growth (economy based on knowledge and innovation through development and improved quality of education and R\&D spending), sustainable growth (resource-efficient economy + modern technologies + environmental protection + new jobs), and inclusive growth (highemployment economy, vocational activation and social inclusion) (GUS (Central Statistical Office) 2014, p. 70).

\section{Trends and challenges in the European labour market}

The labour market is influenced by a number of factors, including: economic, social, cultural, technological and political (Męcina, 2013, p. 3). These are the main determinants of dynamic and often difficult-to-predict changes on the European labour market. According to the European Commission, such key factors also include the process of European and international economic integration, the development of new technologies (information and communication), aging population, low employment and high long-term unemployment rates, and the development of segmentation in the labour markets (insiders protected employees, and outsiders - unprotected employees). The European Commission also points to five key issues in the employment and social areas of Member States. These issues include: rising unemployment rates; the increasing percentage of young people out of school, employment and training; the decline in household incomes; the increasing risk of poverty among people in the productive age; and the increase in inequality in the labour market (Frączek, 2014, p. 106-107).

The labour market in the European Union is very heterogeneous, which is due to the varying dynamics of the economic development of individual Member States (Kacprzak, 2014), the applied models of public policy, and the previously mentioned demographic, cultural and social factors. Undoubtedly, in the coming years, the shape of the EU labour market will be influenced by many different factors. First of all, we should mention structural changes, which are currently being implemented, related to deindustrialisation, increasing employment in the service sector and privatisation of enterprises. Moreover, technological and scientific progress also affects the shape of the EU labour market. Technological changes, such as computerisation and digitalisation, are undoubtedly reflected in the specific character of work of today's businesses, including increased competency requirements, employment reduction, and methods of recruitment of employees and evaluation of their competencies. High volatility, increasing unpredictability and randomness is also noticeable on the labour market. Increased vulnerability and susceptibility to unemployment can be observed as well. The increasing problems related to 
inequality in the labour market (women-men, younger-older, skilled-unskilled, disabled, migrants, differences in income...), population aging and migration of human capital (outflow of specialists, excess or shortage of employees in particular industries, sectors and professions) are the next challenges that need to be addressed in the implementation of the European Union's employment policy (Frączek, 2014, p. 123-124).

Another important issue is the need and ability to adapt and work in multicultural environments and the related increase in the importance of cultural competence of employees in the European labour market. There are clear signs of growth and improvement of professional activity of women and people with disabilities. In the area of employment of migrants, aggravating problems can also be observed. In the European labour market, there may be potential problems attributable to employers' awareness of hiring foreigners (fear of complicated formalities, communication problems, conflicts associated with cultural differences, etc.). There is also a risk of reverse class mobility (increase in social status in the migrant's home country and degradation in the host country), difficulties in transferability of experience acquired abroad (partial, severe, very severe), mobility of specialists in the European labour market (brain exchange, brain drain and brain waste.)

There is also a real need to change the orientation of employment and labour market policies based on the use of public co-management mechanisms (Fraczek, 2014, p. 124).

\section{Human capital - forecasts and demand}

In 1975, the European Centre for the Development of Vocational Training (Cedefop) was established in Thessaloniki. It is a European Union organisation dedicated to promoting the development of education and vocational training in the EU. It is engaged in conducting regular research on forward-looking trends in the European labour market. According to its forecasts, by 2020, the demand for specialists (engineers, scientists and healthcare experts) and medium technical staff will increase. A significant decrease is forecast for the agricultural, mining, fisheries and crafts sectors, whereas growth is anticipated in the business and services sector (welfare, personal services, healthcare, catering, hospitality services and distribution - by more than 14 million) and public services (by more than 5 million). During this period, about 20 million new jobs could be created, while approx. 80 million will be vacated by retirees. At the same time, the statistics show a decrease, by approx. 6 million, in the number of people in working age (15-64 years), and an increase in the population aged $45+$, which is linked to the phenomenon of aging society and indicative of a significant problem that may arise, namely, deficiency of employees in the European labour market (Lazarz, 2011, p. 55-57).

According to the forecasts, in the coming years, there will be further changes in the nature, i.e. profile, of the workplace and the work organisation itself. In addition, further increase in the activity of women, youth and people with disabilities in the labour market is to be observed, and the working conditions provided by employers are to be better adapted to their needs. A further gradual increase in self-employment is also anticipated. International experience, cultural awareness, communication skills, adaptability and coping skills will be increasingly important in shaping and developing human capital. From the point of view of both the labour market and employers in the EU, key employee competencies reflecting global trends (including, among others, environmental and health 
protection, climate-related aspects) can be identified. The following types of competencies can be distinguished: cultural and social competences, such as intercultural skills, teamwork, personal development planning, entrepreneurship and innovation; technical competencies including, for example, ICT skills at user and expert level, skills and knowledge related to new processes and products emerging in the market; skills related to health, climate and sustainable development; skills related to operating, assembling and repairing machines; and management skills - intercultural management in an international environment, as well as management of the international value chain, international finance and sustainable development (implementation and management of policies, solutions/projects which are climate- and environmentally-friendly (Kacprzak, Król, 2015, p. 41).

In the European labour market, the appreciated and desired competencies, as mentioned before, are innovation competencies, manifested above all by awareness of the need for, and skills in regular, lifelong learning, as well as awareness, ability and willingness to initiate and implement changes, and to create, implement and adapt innovations. In addition, what is noticeable about such an employee, is the easiness in accepting even the most unexpected changes coming from the environment and a high degree of susceptibility to external factors that determine such attitudes and behaviours (Król, 2017, p. 42).

A desired competence profile of migrants can be also identified from the employer perspective. It should include such features as experience, creativity, innovative approach, flexibility, mobility, openness to others, cultural and interpersonal competence, as well as communication skills in at least one foreign language.

According to the data held by the European Commission, every ninth specialist who decides to work in his/her profession within the EU, but outside his/her place of residence, is a Polish citizen (Kukliński, 2015).

\section{Quality and development of human capital in the European perspective}

When looking at human capital as an indicator of the position of a person in the labour market, the following dependencies can be observed: the higher the level of human capital, the more certain the position of an individual on the labour market. This idea seems to be equally well expressed in the definition proposed by H. Król and A. Ludwiczyński, which defines human capital as the knowledge, skills, capabilities and potential for development and introduction of innovations, demonstrated by people working in the company. It is also the human factor in an organisation, i.e. the combination of intelligence, skills and expertise, which gives the organisation its specific character (Król, Ludwiczyński, 2006, p.116-117).

The creation of human capital and its quality are largely dependent on the healthcare system, education and employment policy, both at a national and international level. The EU is making efforts towards a dynamically developing knowledge-based world economy, centred around a society focused on lifelong learning. The EU strategies, and measures implemented within their framework, focus mainly on investing in R\&D, education and training. There is no uniform European education model and the Member States are able to create it at their own discretion, on the basis of the European Commission's guidelines and 
financial support from the EU. The Member States, signatories of the Bologna Declaration (19.06.1999), agreed to take measures in order to establish the European Higher Education Area, which would greatly facilitate the comparability, compatibility and coherence of European programmes (staff exchange, student mobility, comparability of competences). Poland also became involved in the implementation of these solutions, among others, by introducing a Diploma Supplement, the European Credit Transfer System, the Qualification Framework; establishing the Polish Accreditation Committee; or joining the Erasmus Student Exchange Programme (Pomianek, 2011, p. 87).

There are some clear trends in European education, including, among others, increased number of children in pre-school education, increased number of students in higher education, a gradual increase of interest in scientific and technological faculties, a widespread and systematic evaluation of the quality of education, the disappearance of differences in access to new technologies, computers and the internet, the promotion of the concept of lifelong learning), and creation of Third-Age Universities at higher education facilities (Pomianek, 2011, p. 88-89). In the face of development of the private education market, an important challenge is to ensure the same level and quality of education as in public institutions.

Table 1. EU internship and vocational training programmes

\begin{tabular}{|c|c|c|}
\hline PROGRAMME & TARGET GROUP & IMPLEMENTED FORM(S) \\
\hline ERASMUS+ & $\begin{array}{l}\text { school students, graduates of } \\
\text { vocational training institutions, } \\
\text { university students, lecturers }\end{array}$ & $\begin{array}{c}\text { practical training, internships, co-financing } \\
\text { of trips }\end{array}$ \\
\hline $\begin{array}{l}\text { LEONARDO DA } \\
\text { VINCI }\end{array}$ & $\begin{array}{l}\text { vocational school students, } \\
\text { unemployed, youth, people entering } \\
\text { the labour market }\end{array}$ & overseas practical training \\
\hline CEEPUS & $\begin{array}{l}\text { Cooperation between universities in } \\
\text { Central European countries }\end{array}$ & $\begin{array}{l}\text { e.g. overseas internships, one-semester } \\
\text { programmes of study, language courses }\end{array}$ \\
\hline $\begin{array}{l}\text { VULCANUS - } \\
\text { practical training } \\
\text { programmes, Japan }\end{array}$ & $\begin{array}{l}\text { for engineering and science students } \\
\text { from the EU Member States }\end{array}$ & industrial practical training in Japan \\
\hline eTwinning & Young people aged 3-19 & $\begin{array}{c}\text { Electronic media - it encourages to explore } \\
\text { and use information and communication } \\
\text { technologies (ICTs) }\end{array}$ \\
\hline ORGANISATIONS & TARGET GROUP & IMPLEMENTED FORM(S) \\
\hline $\begin{array}{l}\text { AISEC a non- } \\
\text { governmental student } \\
\text { organisation }\end{array}$ & Youth & $\begin{array}{l}\text { AISEC a non-governmental student } \\
\text { organisation run by students Youth } \\
\text { development and management of projects } \\
\text { (marketing, information technology, } \\
\text { intercultural education, etc.), overseas } \\
\text { practical training, participation in } \\
\text { international conferences }\end{array}$ \\
\hline AMICUS & $\begin{array}{l}\text { public institutions, non- } \\
\text { governmental organisations - youth } \\
\text { volunteering as the basis }\end{array}$ & $\begin{array}{l}\text { attempt to evaluate European cooperation } \\
\text { projects - civil service, volunteering }\end{array}$ \\
\hline
\end{tabular}

Source: Authors' own elaboration. 
Other important measures, aimed at improving the quality of human capital and its development, include establishment of international $\mathrm{R} \& \mathrm{D}$ collaboration between universities and companies. This is an opportunity for students to gain experience (internships, practical training, volunteering) and develop their practical skills. EU institutions, such as the European Commission, the Council of the European Union, the European Parliament and the European Court of Justice, also provide opportunities for practical and vocational training. For example, the European Commission regularly organises internships, with duration of 3 to 5 months, for holders of Bachelor or Bachelor in Engineering degrees, and very good knowledge of an EU foreign language (English, French or German) and another language from a different Member State (Pomianek, 2011, p. 52-54).

Several practical and vocational training / internship programmes are available in EU companies and non-governmental organisations, as detailed in Table 1.

EU programmes are also of great importance for the development and quality of human capital. Examples of such programmes implemented in Poland include, among others, the Operational Programme: Human Capital (OP HC) 2007-2013, one of the key programmes financed from the European Funds. It has enabled NGOs, entrepreneurs, labour market institutions, as well as local and central government administration to implement a number of projects on a fairly large scale, thus improving competences of employees and individuals involved in economic activity, activating the unemployed in a difficult situation, facing the threat of social exclusion, and facilitating the procedure for setting up your own business.

On 17 December 2014, the European Commission approved the Operational Programme: Knowledge Education Development (OP KED) 2014-2020. The programme covers six priorities - young people on the labour market, effective public policies for the labour market, economy and education, higher education for the economy and development, social innovation and transnational cooperation, health support and technical assistance. The budget of the OP KED comprises EUR 4.4 billion from the European Social Fund, and EUR 252.4 million from the dedicated budget line of the youth employment initiative. (www.kapitalludzki.gov.pl)

\section{Summary}

Human capital was also affected by the worldwide globalisation and integration processes which resulted in the creation of the European Union. Today, it is difficult to predict what new challenges and problems we will have to face, however, by investing in human capital, it will be possible to find a quick solution in any difficult situation. Atypical situations require unconventional thinking and action, hence the particular importance of employee competence in the area of creativity and innovation (Król, 2017, p. 36).

EU Member States recognise the essence and role of human capital in the growth and socio-economic development of countries. Therefore, they undertake a number of joint actions as part of different strategies, the objective of which is to make the use of human capital more effective. For many people, the open European labour market has become an opportunity to pursue a career, or an opportunity to improve their social status and standard of living. However, this has also led to a number of problems and conflicts, especially in connection with the migration of human capital. For most of us, working and learning in a 
multicultural environment has become commonplace. There is an actual need to further define employment, education and training policies and modify labour markets, not only in individual countries, but also at the Community (EU) level. Undoubtedly, the solutions implemented so far have already brought some visible and measurable benefits. Such solutions include, for example, the aforementioned programmes of international exchange of lecturers and students, strengthening of international cooperation in the field of R\&D, or some very successful projects implemented within the framework of the OP HC (Operational Programme: Human Capital) and OP KED (Operational Programme: Knowledge, Education Development).

\section{References}

Frączek, M. (2014). Rynek pracy w Unii Europejskiej - stan, perspektywy i główne determinanty rozwojowe. In: Makuch M. (ed.), Współczesny rynek pracy. Zatrudnienie i bezrobocie w XXI wieku, Wydawnictwo CEdu Sp. z o.o., Wrocław.

Funck, B., Pizzati, L. (2002). Labor, Employment and Social Politicies in the UE Enlargement Process, Bank Światowy, Waszyngton, Europejskie Strategie Zatrudnienia. Accessed from: www.europa.eu.int.

GUS (2014). Polska w Unii Europejskiej 2004-2014. Accessed from: www.stat.gov.pl.

Kacprzak, M. (2014). Local initiatives for the unemployment counteraction in the Mazovia Province. $Z N S G G W$ Polityki Europejskie, Finanse i Marketing, 12(61), 55-63.

Kacprzak, M., Król, A., (2015). Kapitał ludzki na rynku pracy, Turystyka i Rozwój Regionalny 4, 33-44.

Król, A. (2016). Koncepcje zarządzania kapitałem ludzkim w aspekcie procesu globalizacji i kształtowania kultury organizacji. Zarzadzanie. Teoria i praktyka, 18(4), 59-66.

Król, A. (2017). Kreatywność i innowacyjność jako kluczowy element zarządzania kapitałem ludzkim. Zeszyty Naukowe Wyższej Szkoty Promocji, 1, 35-49.

Król, H., Ludwiczyński, A. (2006). Zarządzanie zasobami ludzkimi. Budowanie kapitału ludzkiego organizacji, Wydawnictwo Naukowe PWN, Warszawa.

Kukliński, W. (2015). Drenaż mózgów. Polska traci najwięcej specjalistów w Europie. Accessed from: www.wirtualnapolonia.com.

Łazarz, D. (2011). Trendy na europejskim rynku pracy w perspektywie lat 2015-2020. In: Pomianek T. (ed.), Rynek pracy w Polsce i innych krajach europejskich, Wyższa Szkoła Informatyki i Zarządzania, Rzeszów.

Męcina, J. (2013). Kompromis między bezpieczeństwem a elastycznością zatrudnienia z perspektywy rynku pracy, Dialog, 3(38).

Pomianek, T. (ed.) (2011). Rynek pracy w Polsce i innych krajach europejskich, Wyższa Szkoła Informatyki i Zarządzania, Rzeszów.

Szymańska, A. (2004). Polityka zwiększania efektywności rynku pracy w Unii Europejskiej: lekcje dla Polski, Centrum Europejskie Natolin, Warszawa. 